\title{
A Comparative Study of Customers' Perceptions of Service Quality Dimensions between Public and Private Banks in India
}

\author{
Dr. Neelotpaul Banerjee (Corresponding author) \\ Department of Management Studies, National Institute of Technology, Durgapur-713209, West Bengal, India \\ E-mail: neelotpaul@gmail.com
}

Santosh Sah

Management Trainee, Coal India Ltd, Bilaspur, Chhattisgarh, India

E-mail: santosh.sah12@gmail.com

Received: July 2, 2012

Accepted: July 25, 2012

Online Published: September 12, 2012

doi:10.5430/ijba.v3n5p33

URL: http://dx.doi.org/10.5430/ijba.v3n5p33

\begin{abstract}
Banking firms like other service providing firms are trying to improve their service quality to make customers satisfied with their services in order to survive in the dynamic business environment. This research paper uses the SERVQUAL model to identify the gap between customer expectations and perceptions of the actual service received in public and private banks in India. Outcomes of the study outlined that customers' expectations are more with the private banks and the level of satisfaction is also higher while they deal with the private banks. In order to satisfy the customers the public banks should focus on improving the service in terms of tangibility, reliability, responsiveness and empathy.
\end{abstract}

Keywords: Bank, Customers' expectations, India, Service quality, SERVQUAL

\section{Introduction}

The service sector makes significant contributions to economic and social development of countries around the world (Daniel and Harrington, 2007). At present the service sector plays a critical role in the wealth creation of a nation which is reflected by such indicators like GDP and added value. Most countries with strong economies are dominated by services, which account for more than 70 per cent of their GDP (Ostrom et al., 2010). India is thirteenth in services output. The services sector in India has the largest share in the GDP, accounting for fifty five percent. The Economic Survey 2011-12 suggests that the services sector continues to remain the growth engine for Indian Economy. The Economic Survey points out that the services sector grew by $9.4 \%$ in $2011-12$, which is a little higher than $9.3 \%$ in the previous year. With India experiencing a cycle of growth, the sixty four trillion rupees (US\$ 1.25 trillion) Indian Banking industry is poised to grow exponentially as the sector reflects the health of an economy. Liberalization policy of the government along with the rapid growth in the Indian economy has rejuvenated the banking sector in the country. According to the Reserve Bank of India's 'Quarterly Statistics on Deposits and Credit of Scheduled Commercial Banks', September 2011, bank deposits grew 13.4 per cent to Rs 60.72 trillion (US\$ 1.19 trillion) in the fiscal 2011-12 (the year to March 23, 2011), while loans and advances grew 17.08 per cent to Rs 47.54 trillion (US\$ 930 billion).

Ever since the banks throughout the globe started to operate more commercially, service quality has been identified as the critical ingredient to success, and customers must be satisfied in order to stay ahead of the competitors. After nationalization of commercial banks in India in 1969 and 1980, the ownership of major commercial banks was taken over by the Government. After nationalization, competition was restricted and the banking sector was insulated from world financial markets (Mishra et al., 2010). As a result of the India's liberalisation policy in 1991, the entry of new generation tech-savvy private banks has stimulated a demand for better banking service quality in order to attract and retain customers. In a fiercely competitive market, it is desirable for banks to develop a customer-centric approach for survival and growth by emphasising on customer service. As banks from both the public and private sectors tussle for competitive advantage and make huge investments for redesigning their operation strategies, the evaluation of banking service quality in both these sectors has become extremely important. 
The service quality is an antecedent for success and survival in today's competitive environment. The most central factor to sustainable competitive advantage is to provide the best possible service quality which will result in improved customer satisfaction, customer retention, and profitability (Sureshchandar et al., 2002; Buttle 1996). Past research works have concluded that service quality leads to customer loyalty and attraction of new customers, positive word-of-mouth, employees' satisfaction and commitment, enhanced corporate image, reduced costs and increased business performance (Berry et al., 1989). High service quality allows service providers to differentiate themselves from their competitors and thus gain sustainable competitive advantages in the global market place (Gounaris, et al., 2003).

Customer service quality is the driving force in both the traditional and virtual business worlds. In today's dynamic business environment from the firm's point of view it is about building and sustaining a strong relationship with their customers by understanding the ingredients of customer satisfaction. The key to customer loyalty is customer satisfaction which largely depends on the service quality offered by service providing firms. Service quality and customer satisfaction have been identified as key elements of the service-profit chain (Heskett et al., 1997). Better service quality results in enhanced customer satisfaction, which in turn leads to strong customer loyalty. It can be stated that customers, when satisfied with the services they have experienced, are more likely to establish loyalty (Taylorv et.al, 1992), resulting in repeat purchases (Fornell, 1992) and favorable word-of-mouth (Halstead \& Page, 1992). Customer service quality is a significant source of distinctive competence and often considered a key success factor in sustaining competitive advantage in service industries (Palmer, 2001). Quality in service is quite different from quality of goods. The dimensions of service quality are defined mostly from customers' expectations and are extremely difficult to measure in quantitative terms.

Quality in service can be determined by the extent to which customers' needs and expectations can be satisfied. Various concepts and models have been developed over the years to measure customer satisfaction. The majority of the work to date has attempted to use the SERVQUAL (Parasuraman et al., 1985; 1988) methodology in an effort to measure service quality (Brooks et al., 1999; Chaston, 1994; Edvardsson et al., 1997; Lings and Brooks, 1998; Sahney et al., 2004). The present study uses the SERVQUAL instrument developed by Parasuramn et al. (1985). Since its development SERVQUAL has gained wide scale acceptance and has proven to be a popular measurement tool with academicians and practitioners alike. SERVQUAL has been widely used in research studies across a range of service industries (Carman, 1990), and has become a standard in measuring service quality (DeMoranville \& Bienstock, 2003).

SERVQUAL consists of five service dimensions with a set of 22 items, each item measuring both the perception and the expectation of a particular service attribute. The five generic service dimensions are tangibles, responsiveness, assurance, empathy and reliability. SERVQUAL measures the difference between what is expected from a service encounter and the perception of the actual service encounter. In the SERVQUAL instrument, 22 statements measure the performance across these five dimensions, using a seven point likert scale measuring both customer expectations and perceptions (Gabbie and O'neill, 1996).

The objectives of this study are - a) to assess customers' expectation and perception level towards service quality of public and private banks in India using SERVQUAL model, b) to find the service quality gap between the customers' expectation and perception of the service quality of the public and private banks, and c) to compare the service gap between the private and public sector banks.

\section{Literature Review}

The importance of service quality for the success of business has been substantiated in the literature through a plethora of studies. Previous research works offer many valuable contributions related to the measurement of service quality using the SERVQUAL model.

The term quality has been variously defined as value (Feizenbaum, 1951), conformance to requirements (Crosby, 1979), fitness for use (Juran et al., 1974).

Parasuraman and Berry (1988) pointed out that with the fast changing, fierce market conditions prevalent within the service trade, improvements in terms of competitiveness and yield rates rely on effective, active, and improved service quality. Service quality is the extent to which a service meets customers' needs or expectations (Lewis \& Mitchell, 1990; Dotchin \& Oakland, 1994; Asubonteng et al., 1996). Service quality can thus be defined as the difference between customer expectations of service and perceived service. If performance is greater than expectation, then perceived quality is satisfactory resulting in customer satisfaction occurs. 
Expectations are viewed as predictions made by customers about what they are likely to experience during the transaction. Different customers have different expectation based on the customer's knowledge of a product or service. Davidow and Uttal (1989) proposed that customers' expectation is formed by many uncontrollable factors which include previous experience with other companies, and their advertising, customers' psychological condition at the time of service delivery, customer background and values and the images of the purchased product. In addition, Zeithaml et al. (1990) stated that customer service expectation is built on complex considerations, including their own pre-purchase beliefs and other people's opinions Customers, expectation can be defined as customer's partial beliefs about a product (McKinney et al., 2002). Perceived performance is defined as customer's perception of how product performance fulfills their needs, wants and desire (Cadotte et al., 1987). Perceived quality of a product or service is how the customers feel about the product's or service's excellence.

Reeves and Bednar (1994) defined service quality as excellence, value, conformance to specifications and meeting or exceeding customers' expectations. Bitner and Hubbert (1994) defined service quality as the customers' overall impression of the relative inferiority or superiority of the organization and its services. Ueltschy et al. (2004) defined service quality as the consumer's judgment about the overall excellence or superiority of the service. Service quality is not objectively measured according to some technical standards but is subjectively felt by customers and measured relative to customer-determined standards (Kwortnik, 2005).

Baker and Crompton (2000) suggested that perceived service quality directly and significantly influences satisfaction. Choi et al., (2004) found that service quality emerged as an important determinant of customer satisfaction and service quality had a significant impact on behavioral intentions of customers. Gonzalez et al., (2007) demonstrated the influence of service quality and customer satisfaction on customer behavioral intentions. Vijayadurai (2008) indicated that service quality is an important driver of customer satisfaction and behavioral intentions. Zabkar et al., (2010) indicated that perceived service quality positively related to visitors satisfaction as well as visitors' behavioral intentions.

Previous research studies have shown that customer satisfaction reduces future transactions costs (Reichheld and Sasser, 1990), secures future revenues (Bolton, 1998; Fornell, 1992), minimizes the likelihood of customers defecting if quality falters (Anderson and Sullivan, 1993) and decreases price elasticity (Anderson, 1996).

The SERVQUAL model has been examined, discussed and implemented to measure and assess service quality across different service, industrial, commercial, and non-profit settings (Ladhari, 2008), including, health-care sector (Headley and Miller, 1993; Kilbourne et al., 2004); hotels (Saleh \& Ryan, 1991); travel and tourism (Fick \& Ritchie, 1991); car servicing (Bouman \& van der Wiele, 1992); higher education (McElwee \& Redman, 1993); hospitality (Johns, 1993), business-to-business channel partners (Kong \& Mayo, 1993); recreational services (Taylor et al., 1993); hospitals (Babakus \& Mangold, 1992; Reidenbach \& Sandifer-Smallwood, 1990; Vandamme \& Leunis, 1993; Walbridge \& Delene, 1993).

Thus, service quality directly affects customer satisfaction. The same holds true for the banking industry. In order to successfully operate bank managers need to understand what customer want and how they assess the banking service quality. Levesque and McDougall (1996), in their quest for understanding customer satisfaction in retail banking, concluded that a good "employee-customer" relationship can enhance the customers' satisfaction level. Jamal and Naser (2003) from their study found that convenience and competitiveness are not the critical factors, in case of banks in Pakistan, for all gender, age and income groups. Arasli et al., (2005) stated that reliability dimension of SERVQUAL has the greatest impact on customer satisfaction in Greek Cypriot banking industry. Baumann et al. (2007) found that tangibles do not have any impact on banks customers' satisfaction. Kumar et al., (2010) stated that assurance, empathy and tangibles are the important factors in case of banking services. Ahmed et al. (2010) found that empathy is negatively related to customer satisfaction with banking service.

At present, there is little research work in the banking service context in India, albeit, studies being aplenty in other countries. The present study has been undertaken to throw some light on that gap that exists in the literature.

\section{Research Methodology}

The questionnaire for the measurement of service quality followed the basic structure of the SERVQUAL instrument as developed by Parasuraman et al. (1991). The questionnaire consisted of two sections - a) expectation section, and b) perception section. The original SERVQUAL instrument employed a 7-point scale (Parasuraman et al., 1991). Hence in this study for measuring customer-perceived service quality, the authors employed a 7-point scale, anchored by strongly disagree and strongly agree at the endpoints 1 and 7, respectively. 
The samples consisted of customers living in a major city, with a large and diverse population, in the state of West Bengal. The sampling method used in this study is convenience sampling. Convenience samples are selected at the convenience of the researcher (Neelankavil, 2007). For the present study two banks each in the private and public sector are taken. The respondents are chosen from the customers coming out of the private or public banks, where it would be easy to invite them to take part in the research. In total 230 respondents completed the questionnaire, out of which 107 have accounts in private banks and 123 have accounts in public banks.

SPSS version 16.0 was used to carry out the analysis of data.

\section{Findings and Analysis}

The demographic details of the respondents are given in Table 1.

\subsection{Service Quality GAP (P-E) in Public Sector Banks}

The scores for each of the dimensions bear the negative sign meaning that expectations are greater than performance. From the table 2, it can be stated in case of the public sector banks, the service GAP between customers' perception and expectation is maximum for the service dimension Responsiveness (-1.04). This indicates that in case of public sector banks in India the banks fail to provide prompt service, employees are busy and not that willing to help the customers, and do not communicate clearly when services will be delivered. So the public sector banks lack of responsiveness can be considered as the major source for customers' dissatisfaction. In case of the service dimension Assurance the gap is the least (-0.46). Although this service dimension does not meet customers' expectations but still customers perceive that public sector banks are better in giving assurance to customers than providing other banking services.

\subsection{Service Quality GAP (P-E) in Private Sector Banks}

The scores for each of the dimensions are negative which implies that customers' perceived banking service quality is less than expected and thus service quality gap exists. From the table 3, it can be stated in case of the private sector banks, the service quality GAP between customers' perception and expectation is maximum for the service dimension Assurances (-0.63). This indicates the private sector banks should focus more on customers perceptions about transaction safety, employee behaviour, employee courtesy, and employees' to answer customers' questions, than other service dimensions. In case of the service dimension Reliability the gap is the least (-0.46).

From table 2 and table 3, it is seen that the service quality gap (P-E) scores are considerably lower for private sector banks in comparison to public sector banks for the service dimension tangible, reliability, responsiveness, and empathy. The score for the service dimension assurance is lower in case of public sector banks.

\subsection{Data Testing for Normality}

An assessment of the normality of data is a prerequisite for many statistical tests as normal data is an underlying assumption in parametric testing. So the data set is tested for normal distribution. The term normal distribution refers to a particular way in which observations will tend to pile up around a particular value rather than be spread evenly across a range of values.

In this study the Kolmogorov-Smirnov test (K-S test) is used for checking the normality. In terms of hypothesis testing, the Kolmogorov-Smirnov test is based on Ho: that the data are normally distributed.

If the Kolmogorov-Smirnov $\mathrm{Z}$ test yields a significance level of less than 0.05 , it means that the distribution is not normal. If the Kolmogorov-Smirnov $Z$ test yields a significance level of more than 0.05 , it means that the distribution is normal.

From table 4, it can be concluded the data set is not normally distributed as for each variable the significance value is less than 0.05 . Hence, null hypothesis is rejected and alternative hypothesis is accepted. So, the data are not normally distributed.

\subsection{Comparison of the Customers' Perceptions of Public and Private Sector Banking Services}

As the data are not normally distributed so Mann Whitney $U$ test is used for the comparison of the service quality gap between the private and public banks. In the field of behavioural sciences, the Mann-Whitney U test is one of the most commonly used non-parametric statistical tests (Kasuya, 2001). The Mann-Whitney U Test is used to compare differences between two independent groups when the dependent variable is either (a) ordinal or (b) interval but not normally distributed. It is the nonparametric alternative to the independent t-test.

The Mann Whitney $U$ test is used to compare the perceptions of customers toward the different attributes of the service dimensions between private and public sector banks. 
Ho: there are no significant differences in the attributes of the service dimensions between private and public banks $H_{1}$ : there are significant differences in the attributes of the service dimensions between private and public banks

From the table 5 , it is evident that the service quality gaps significantly differ between private sector and public sector banks in the following dimensions:

i) Tangibility: There is statistically significant difference in the service gap in the attributes physical facilities visually appealing ( $p=0.004)$, employees have neat appearance $(p=0.001)$, materials associated with service visually appealing $(p=0.000)$, between the private and public sector banks in India. In case of all the attributes of tangibility the mean ranks of private banks are higher than the public sector banks. This indicates that in case of private banks the physical facilities and decor are more attractive, and the employees are also more impressive in their appearances than the public banks. So the look and feel good factor is more evident in the private banks.

ii) Reliability: The difference between customers' perception and expectation against the attributes of this dimension varies significantly $(p=0.000)$ between the public and private banks. In addition to that, the mean ranks of all the items under the dimension reliability are higher in case of private sector banks in comparison to the public sector banks. This may imply that customers feel the private banks have better ability to perform the promised services dependably and accurately. So the customers invest more trust in private banks than the public banks.

iii) Responsiveness: There is statistically significant difference in the service quality gap in only one attribute $i, e$. prompt service $(p=0.002)$ under this service dimension between the private and public sector banks in India. But the mean ranks of all the items under the dimension responsiveness are higher in case of private sector banks in comparison to the public sector banks. The Indian customers' perceive that employees in the private sectors banks exhibit higher willingness to help customers and provide prompt service than their public banks counterparts.

iv) Assurance: There is statistically significant difference in the service gap in two attributes employee behaviour instil confidence in customers $(p=0.011)$, and feel safe in transactions $(p=0.004)$ between the private and public sector banks in India. The mean rank of the item feel safe in transactions is higher in case of public sector banks in comparison to the private sector banks. This shows that customers' perceived risks in banking transactions are less in case of public sector banks in comparison to private sector banks. Indian customers' perceive the level of courtesy shown by employees in both the private and public sector banks are more or less same. For the other two attributes, namely, employee behaviour instil confidence in customers, and employees have knowledge to answer customers' questions the mean ranks are higher in case of private sector banks than the public sector banks.

In case of the service dimension empathy there is no statistically significant difference in any of the attributes between the private and public bank

\section{Conclusion}

Customers' expectation of private banks is more than the public banks in case of all the service dimensions. This indicates that customers expect better services in private banks than in public banks, and as a result may be more interested in conducting transactions with the private banks. Customers believe that the chance of getting satisfactory service is more with the private banks.

The service gap (P-E) scores are considerably lower for private sector banks in comparison to public sector banks for the service dimension tangible, reliability, responsiveness, and empathy.

In case of public banks the service gap is the highest in the responsiveness dimension. So employees not being responsive are a major concern for the public sector banks, and the banks should put major emphasis to make the employees more responsive toward customers concerns and queries. In case of public banks the service gap is the lowest in the assurance dimension. So, public banks in India are better in assertion and generating confidence in customers than in providing other banking services. Employees are part of the customer service process, which is a critical element for building customer loyalty. These interactions between the employees and the customers during a service are significant determinants of overall customer satisfaction.

The service gap is highest in assurance dimension for private banks which may indicate that the employees in these banks may need to enhance their occupational knowledge, instil confidence in customers and make them feel safe in transactions.

In case of private banks the service gap is lowest in reliability dimension and it may imply that customers feel these banks to be sincere and keep their promises. According to Zeithaml et al. (1990), service providers' apologies start to wear thin when a company is careless in performing the service, when it makes frequent mistakes and when it is casual about keeping its service promises. Hence, it is quintessential to provide excellent service at the first time, 
exhibit sincere effort in solving customers' problems, provide error free record and constantly fulfil promises to prevent customers from defecting to other banks. The private banks provide the human touch aspect of the banking service better than the public banks and thus are able to acquire and retain more customers.

From the Mann Whitney $U$ test it is evident that between the private and public sector banks in India, there is significant difference in the three out of the four attributes included in the service dimensions tangible, and in all the five attributes of the dimension reliability. So it can be stated that private banks are providing better physical facilities and reliable services than their public sector counterparts. Customers' level of satisfaction in case of the dimension empathy does not differ significantly between the public and private banks which implies that operating hours of the private and public banks are more or less same in convenience and employees desire to understand the customers does not differ much in the two types of banks.

Overall from this study it can be concluded that customers' expectations are more with the private banks and the level of satisfaction is also higher while they deal with the private banks. Competition wise the private banks are moving ahead of the public sector banks. In order to satisfy the customers and gain their patronage the public banks should focus on improving the service in terms of tangibility, reliability, responsiveness and empathy. The private banks appear to be a better option as perceived by the customers but they should try to provide services so as to assure the customers and give them confidence. In order to achieve success business firms should focus on customer oriented services, which will lead to long term bonding with their customers. It can be concluded that private banks have been successful to a greater extent in achieving such relationship with customers than the public sector banks.

\section{References}

Ahmed, I., Nawaz, M.,Usman, A., Shaukat, M., Ahmad, N., \& Iqbal, H. (2010). Impact of Service Quality on Customers' Satisfaction: Empirical evidence from telecom sector of Pakistan. Interdisciplinary Journal of Contemporary Research in Business, 1(12), 98-113.

Anderson E.W., \& Sullivan, M. (1993). The antecedents and consequences of customer satisfaction for firms. Marketing Science, 12(2), 125-143. http://dx.doi.org/10.1287/mksc.12.2.125

Anderson, E.W. (1996). Customer satisfaction and price tolerance. Marketing Letters, 7(3), 19-30. http://dx.doi.org/10.1007/BF00435742

Arasli, H., Smadi, S. M., \& Katircioglu, S. T. (2005). Customer Service Quality in the Greek Cypriot banking industry. Managing Service Quality, 15(1), 41-56. http://dx.doi.org/10.1108/09604520510575254

Asubonteng, P., McCleary, K.J., \& Swan, J.E. (1996). SERVQUAL revisited: a critical review of service quality. Journal of Services Marketing, 10(6), 62-81. http://dx.doi.org/10.1108/08876049610148602.

Babakus, E., \& Mangold,W.G. (1992). Adapting the SERVQUAL scale to hospital services: An empirical investigation. Health Service Research, 26(2), 767-786.

Baker, D., \& Crompton, J. (2000). Quality, Satisfaction and Behavioral Intentions. Annals of Tourism Research, 27(3), 785-804. http://dx.doi.org/10.1016/S0160-7383(99)00108-5

Baumann, C., Burton, S., Elliott, G., \& Kehr, H. (2007). Prediction of attitude and behavioural intentions in retail banking. The International Journal of Bank Marketing, 25(2), 102-116. http://dx.doi.org/10.1108/02652320710728438

Berry, L.L., Bennett, D., \& Brown, C. (1989). Service quality: A Profit Strategy for Financial Institutions. Irwin Professional Pub.

Bitner, J.M., \& Hubbert, A.R. (1994). Encounter Satisfaction versus Overall Satisfaction versus Quality. In Rust, R. \& Oliver, R. (Eds.), Service Quality: New Directions in Theory and Practice (pp. 72-94). Sage, Thousand Oaks, CA.

Bolton, R.N. (1998). A dynamic model of the duration of the customer's relationship with a continuous service provider: the role of customer satisfaction. Marketing Science, 17(1), 45-65. http://dx.doi.org/10.1287/mksc.17.1.45

Bouman, M., \& Van der Wiele, T. (1992). Measuring service quality in the car service industry: building and testing an instrument, International Journal of Service Industry Management, 3(4), 4-16. http://dx.doi.org/10.1108/09564239210019441.

Brooks, R.F., Lings, I.N., \& Botschen, M.A. (1999). Internal marketing and customer driven wavefronts. Service Industries Journal, 19(4), 49-67. http://dx.doi.org/10.1080/02642069900000044

Buttle, F. (1996). SERVQUAL: Review, Critique, Research Agenda'. European Journal of Marketing, 30(1), 8-32. http://dx.doi.org/10.1108/03090569610105762. 
Cadotte, E. R., Woodruff, R.B., \& Jenkins, R.L. (1987). Expectations and norms in models of consumer satisfaction. Journal of Marketing Research, 24(3), 305-314. http://dx.doi.org/10.2307/3151641

Carman, J.M. (1990). Consumer Perceptions of Service Quality: An Assessment of the SERVQUAL Dimensions. Journal of Retailing, 66(1), 33-55.

Chaston, I. (1994). Internal customer management and service gaps within the UK manufacturing sector. International Journal of Operations and Production, 14(9), 45-56. http://dx.doi.org/10.1108/01443579410066758.

Choi, K.S., Cho, W.H., Lee, S., Lee, H., \& Kim, C. (2004). The Relationships Among Quality, Value, Satisfaction and Behavioral Intention in Health Care Provider Choice: A South Korean Study. Journal of Business Research, 57, 913-921. http://dx.doi.org/10.1016/S0148-2963(02)00293-X

Crosby, P.B. (1979). Quality is Free: The Art of Making Quality Certain. New American Literary, New York.

Daniel, P.W., \& Harrington, J.W. (2007). Services and Economic Development in the Asia-Pacific, Ashgate.

DeMoranville, C.W., \& Bienstock, C.C. (2003). Question Order Effects in Measuring Service Quality. International Journal of Research in Marketing, 20(3), 217-231. http://dx.doi.org/10.1016/S0167-8116(03)00034-X

Dotchin, J.A., \& Oakland, J.S. (1994). Total quality management in services: Part 2 Service quality. International Journal of Quality \& Reliability Management, 11(3), 27-42. http://dx.doi.org/10.1108/02656719410056468

Edvardsson, B., Larsson, G., \& Setterlind, S. (1997). Internal service quality and the psychological work environment: an empirical analysis of conceptual interrelatedness. Service Industries Journal, 17(2), 252-63. http://dx.doi.org/10.1080/02642069700000014

Feizenbaum, A.V. (1951). Quality Control: Principles, Practice and Administration. McGraw-Hill,NewYork.

Fick, G.R., \& Ritchie, J.R.B. (1991). Measuring service quality in the travel and tourism industry. Journal of Travel Research, 30(2), 2-9. http://dx.doi.org/10.1177/004728759103000201.

Fornell, C. (1992). A National Customer Satisfaction Barometer: the Swedish Experience. Journal of Marketing, 56(1), 6-21. http://dx.doi.org/10.2307/1252129

Gabbie, O., \& O'Neill, M.A. (1996). SERVQUAL and the northern Ireland hotel sector: A comparative analysis Part 1. Managing Service Quality, 6(6), 25-32. http://dx.doi.org/10.1108/09604529610149194

Gonzalez, M.E.A., Comesana, L.R., \& Brea, J.A.F. (2007). Assessing Tourist Behavioral Intentions Through Perceived Service Quality and Customer Satisfaction. Journal of Business Research, 60, 153-160. http://dx.doi.org/10.1016/j.jbusres.2006.10.014

Gounaris, S., Stathakopoulos, V., \& Athanassopoulos, A. (2003). Antecedents to perceived service quality: an exploratory study in the banking industry. International Journal of Bank Marketing, 21(4), 168-190. http://dx.doi.org/10.1108/02652320310479178

Halstead, D., \& Page Jr., T.J. (1992). The Effects of Satisfaction and Complaining Behavior on Consumers Repurchase Behavior. Journal of Satisfaction, Dissatisfaction and Complaining Behavior, 5, 1-11.

Heskett, J.L., Sasser, W. E., \& Schlesinger, L.A. (1997). The Service Profit Chain: How Leading Companies Link Profit and Growth to Loyalty, Satisfaction and Value. Free Press, New York.

Jamal, A., \& Naser, K. (2003). Factors influencing customer satisfaction in the retail banking sector in Pakistan. International Journal of Commerce and Management, 13(2), 29. http://dx.doi.org/10.1108/eb047465

Johns, N. (1993). Quality management in the hospitality industry, part 3: recent developments. International Journal of Contemporary Hospitality Management, 5(1), 10-15. http://dx.doi.org/10.1108/09596119310026242.

Juran, J.M., Gryna, F.M., \& Bingham, R.S. (1974). Quality Control Hand Book. McGraw-Hill, New York.

Kasuya, E. (2001). Mann - Whitney U test when variances are unequal. Animal Behavior, 61, 1247-124. http://dx.doi.org/10.1006/anbe.2001.1691

Kilbourne, W.E., Duffy, J.A., Duffy, M., \& Giarchi, G. (2004). The applicability of SERVQUAL in cross-national measurements of health-care quality. Journal of services Marketing, 18(6/7), 524-533. http://dx.doi.org/10.1108/08876040410561857

Kong, R., \& Mayo, M.C. (1993). Measuring service quality in the business-to-business context. Journal of Business and Industrial Marketing, 8(2), 5-15. http://dx.doi.org/10.1108/08858629310041393 
Kumar, S. A., Mani, B. T., Mahalingam, S., \&Vanjikovan, M. (2010). Influence of Service Quality on Attitudinal Loyalty in Private Retail Banking: an empirical study. IUP Journal of Management Research, 9(4), 21-38.

Kwortnik, R.J. (2005). Preparing for Disaster: Recommendations Based on the Blackout of 2003. Cornell Hotel and Restaurant Administration Quarterly, 46(1), 47-51. http://dx.doi.org/10.1177/0010880404272016

Ladhari, R. (2008). Alternative measure of service quality: a review. Journal of Managing Service Quality, 18(1), 65-86. http://dx.doi.org/10.1108/09604520810842849

Levesque, T., \& McDougall, G. (1996). Determinants of customer satisfaction in retail banking. International Journal of Bank Marketing, 14(7), 12-20. http://dx.doi.org/10.1108/02652329610151340

Lewis, B.R., \& Mitchell, V.W. (1990). Defining and measuring the quality of customer service. Marketing Intelligence \& Planning, 8(6), 11-17. http://dx.doi.org/10.1108/EUM0000000001086

Lings, I.N., \& Brooks, R.F. (1998). Implementing and measuring the effectiveness of internal marketing. Journal of Marketing Management, 14, 325-51. http://dx.doi.org/10.1362/026725798784959426

McElwee, G., \& Redman, T. (1993). Upward appraisal in practice: an illustrative example using the QUALED scale. Education and Training, 35(2), 27-31. http://dx.doi.org/10.1108/EUM0000000000298

McKinney, V., Yoon, K., \& Zahedi, F.M. (2002, September). The Measurement of Web-Customer Satisfaction: An expectation and Disconfirmation Approach. Information System Research, 13(3), 296-315. http://dx.doi.org/10.1287/isre.13.3.296.76

Mishra, U.S., Sahoo, K.K., Mishra, S., \& Patra, S.K. (2010). Service Quality Assessment in Banking Industry of India: A Comparative Study between Public and Private Sectors. European Journal of Social Sciences, 16(4), 653-669.

Neelankavil, J. P. (2007). International Business Research. M.E.Sharpe, Inc, New York.

Ostrom, A., Bitner, M., Brown, S., Burkhard, K., Goul, M., \& Smith-Daniels, V., et al. (2010). Moving forward and making a difference: Research priorities for the science of service. Journal of Service Research, 13(1), 4-36. http://dx.doi.org/10.1177/1094670509357611

Palmer, A. (2001). Principles of Service Marketing. McGraw-Hill, New York, 227.

Parasuraman, A., Zeithaml, V.A., \& Berry, L. L. (1985). A Conceptual Model of Service Quality and Its Implications of Future Research. Journal of Marketing, 49, 41-50. http://dx.doi.org/10.2307/1251430

Parasuraman, A., Zeithaml, V.A., \& Berry, L. L. (1988). SERVQUAL: a multi-item scale for measuring consumer perceptions of service quality. Journal of Retailing, 64(1), 12-40.

Parasuraman, A., Zeithaml, V. A., \& Berry, L. L. (1991). Refinement And Reassessment of The SERVQUAL Scale. Journal Of Retailing, Winter, 67(4), 420-450.

Reeves, C. A., \& Bednar, D. A. (1994). Defining Quality: Alternatives and Implications. The Academy of Management Review, 19(3), 419-445. http://dx.doi.org/10.5465/AMR.1994.9412271805

Reidenbach, R. E., \& Sandifer-Smallwood, B. (1990). Exploring perceptions of hospital operations by a modified SERVQUAL approach. Journal of Health Care Marketing, 10(4), 47-55.

Reichheld, F.F., \& Sasser, W. E. (1990). Zero defections: quality comes to services. Harvard Business Review, 68(5), 105-111.

Sahney, S., Banwet, D. K., \& Karunes, S. (2004). A SERVQUAL and QFD approach to total quality education: A student perspective. International Journal of Productivity and Performance Management, 53(2), 143-166. http://dx.doi.org/10.1108/17410400410515043

Saleh, F., \& Rayan, C. (1991). Analysing service quality in the hospitality industry using the SERVQUAL model. Service Industries Journal, 11(3), 324-343. http://dx.doi.org/10.1080/02642069100000049

Sureshchander, G.S., Rajendran, C., \& Anatharaman, R.N. (2002). The relationship between service quality and customer satisfaction: a factor specific approach. Journal of Services Marketing, 16(4), 363-79. http://dx.doi.org/10.1108/08876040210433248

Taylor, S.A., Sharland, A., Cronin, A.A. Jr., \&Bullard, W. (1993). Recreational quality in the international setting. International Journal of Service Industries Management, 4(4), 68-88. http://dx.doi.org/10.1108/09564239310044316 
Ueltschy, L.C., Laroche, M., Tamilia, R.D., \& Yannopoulos, P. (2004). Cross-cultural Invariance of Measures of Satisfaction and Serivce Quality. Journal of Business Research, 57, 901-912. http://dx.doi.org/10.1016/S0148-2963(02)00294-1

Vandamme, R., \& Leunis, J. (1993). Development of a multiple-item scale for measuring hospital service quality. International Journal of Service Industry Management, 4(3), 30-49. http://dx.doi.org/10.1108/09564239310041661

Vijayadurai, J. (2008). Service Quality, Customer Satisfaction and Behavioral Intention in Hotel Industry. Journal of Marketing \& Communication, 3(3), 14-26.

Walbridge, S.W., \& Delene, L.M. (1993). Measuring physician attitudes of service quality. Journal of Health Care Marketing, 13(4), 6-15.

Zabkar, V., Brencic, M.M., \& Dmictrovic, T. (2010). Modelling Perceived Quality, Visitor Satisfaction and Behavioral Intentions at the destination level. Journal of Tourism Management, 31, 537-546. http://dx.doi.org/10.1016/j.tourman.2009.06.005

Zeithaml V.A., Parasuraman A., \& Berry L.L. (1990). Delivering quality service: Balancing customer perceptions and expectations. The Free Press, New York. NY. [Online] Available: http://www.ibef.org/industry/banking.aspx (September 6, 2012)

Table 1. Demographic data

\begin{tabular}{|c|c|c|}
\hline \multicolumn{3}{|l|}{ GENDER } \\
\hline & Frequency & Percent \\
\hline Male & 117 & 50.9 \\
\hline Female & 113 & 49.1 \\
\hline Total & 230 & 100.0 \\
\hline \multicolumn{3}{|l|}{ AGE (in years) } \\
\hline & Frequency & Percent \\
\hline $18-20$ & 18 & 7.8 \\
\hline $21-30$ & 79 & 34.3 \\
\hline $31-40$ & 67 & 29.1 \\
\hline $41-50$ & 36 & 15.7 \\
\hline $51-60$ & 19 & 8.3 \\
\hline Above 60 & 11 & 4.8 \\
\hline Total & 230 & 100.0 \\
\hline \multicolumn{3}{|l|}{ EDUCATION } \\
\hline Post graduate & 107 & 46.5 \\
\hline Graduate & 76 & 33.0 \\
\hline Higher secondary & 30 & 13.1 \\
\hline Secondary & 17 & 7.4 \\
\hline Total & 230 & 100.0 \\
\hline \multicolumn{3}{|c|}{ MONTHLY FAMILY INCOME (in Indian Rupees) } \\
\hline Less than 10000 & 14 & 6.1 \\
\hline $10001-20000$ & 24 & 10.4 \\
\hline $20001-30000$ & 52 & 22.6 \\
\hline $30001-40000$ & 88 & 38.3 \\
\hline $40001-50000$ & 27 & 11.7 \\
\hline Greater than 50000 & 25 & 10.9 \\
\hline Total & 230 & 100.0 \\
\hline \multicolumn{3}{|l|}{ STATUS } \\
\hline Student & 45 & 19.6 \\
\hline Service & 112 & 48.7 \\
\hline Self Employed & 39 & 16.9 \\
\hline Housewife & 19 & 8.3 \\
\hline Retired & 15 & 6.5 \\
\hline Total & 230 & 100.0 \\
\hline
\end{tabular}


Table 2. Service Quality GAP (P-E) in public sector banks

\begin{tabular}{|l|l|l|l|}
\hline DIMENSION & EXPECTATION (E) & PERCEPTION (P) & P-E \\
\hline TANGIBLE & 5.48 & 4.89 & -0.59 \\
\hline RELIABLITY & 5.70 & 4.87 & -0.83 \\
\hline RESPONSIVENESS & 5.69 & 4.65 & -1.04 \\
\hline ASSURANCE & 5.34 & 4.88 & -0.46 \\
\hline EMPATHY & 5.73 & 5.21 & -0.52 \\
\hline
\end{tabular}

Table 3. Service Quality GAP (P-E) in private sector banks

\begin{tabular}{|l|l|l|l|}
\hline DIMENSION & EXPECTATION (E) & PERCEPTION (P) & P-E \\
\hline TANGIBLE & 6.02 & 5.72 & -0.30 \\
\hline RELIABLITY & 6.04 & 5.77 & -0.27 \\
\hline RESPONSIVENESS & 6.08 & 5.63 & -0.45 \\
\hline ASSURANCE & 5.70 & 5.17 & -0.63 \\
\hline EMPATHY & 6.03 & 5.56 & -0.47 \\
\hline
\end{tabular}

Table 4. Kolmogorov-Smirnov test

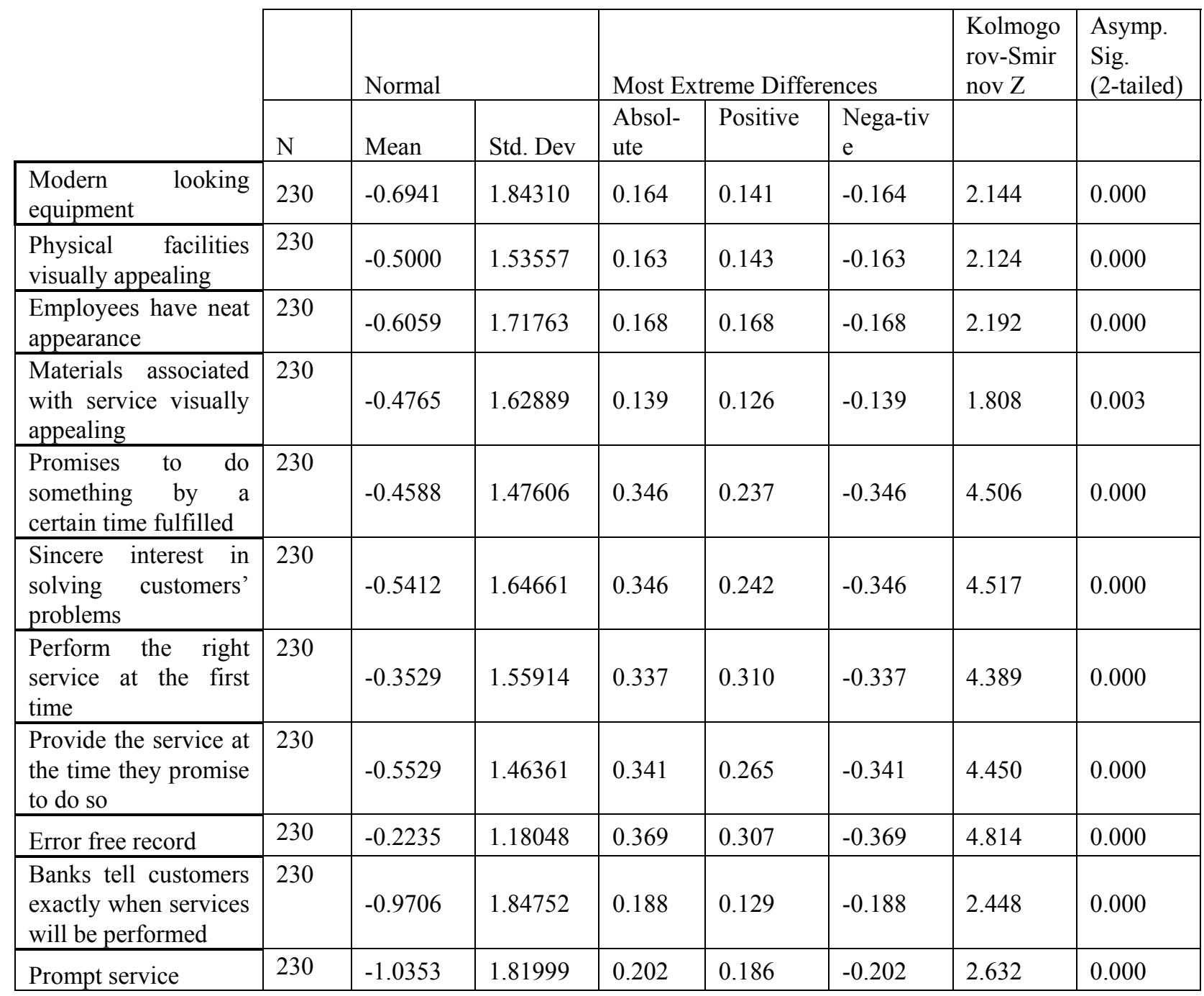




\begin{tabular}{|l|l|l|l|l|l|l|l|l|}
\hline $\begin{array}{l}\text { Willing to help } \\
\text { customers }\end{array}$ & 230 & -1.1059 & 1.81723 & 0.153 & 0.130 & -0.153 & 1.989 & 0.001 \\
\hline $\begin{array}{l}\text { Never be too busy to } \\
\text { respond to customers' } \\
\text { requests }\end{array}$ & 230 & -0.9000 & 1.92968 & 0.143 & 0.092 & -0.143 & 1.866 & 0.002 \\
\hline $\begin{array}{l}\text { Employee behaviour } \\
\text { instil confidence in } \\
\text { customers }\end{array}$ & 230 & -0.8471 & 1.88740 & 0.156 & 0.133 & -0.156 & 2.033 & 0.001 \\
\hline $\begin{array}{l}\text { Feel safe in } \\
\text { transactions }\end{array}$ & 230 & -0.5000 & 1.65787 & 0.177 & 0.140 & -0.177 & 2.312 & 0.000 \\
\hline Employee courteous & 230 & -0.6353 & 1.79643 & 0.144 & 0.144 & -0.130 & 1.880 & 0.002 \\
\hline $\begin{array}{l}\text { Employees have } \\
\text { knowledge to answer } \\
\text { customers' questions }\end{array}$ & 230 & -0.7941 & 1.84903 & 0.162 & 0.151 & -0.162 & 2.106 & 0.000 \\
\hline $\begin{array}{l}\text { Individual attention } \\
\text { to customers }\end{array}$ & 230 & -0.7176 & 1.93450 & 0.191 & 0.191 & -0.162 & 2.485 & 0.000 \\
\hline $\begin{array}{l}\text { Convenient operating } \\
\text { hours }\end{array}$ & 230 & -0.4412 & 1.76741 & 0.225 & 0.225 & -0.210 & 2.933 & 0.000 \\
\hline $\begin{array}{l}\text { Give customers } \\
\text { personal service }\end{array}$ & 230 & -0.5706 & 1.67765 & 0.164 & 0.137 & -0.164 & 2.134 & 0.000 \\
\hline $\begin{array}{l}\text { The Bank has their } \\
\text { customers' } \\
\text { interest at heart. }\end{array}$ & 230 & -0.6118 & 1.61424 & 0.159 & 0.146 & -0.159 & 2.078 & 0.000 \\
\hline $\begin{array}{l}\text { Understand the } \\
\text { specific needs of their } \\
\text { customers }\end{array}$ & 230 & -0.6294 & 1.71946 & 0.151 & 0.151 & -0.149 & 1.972 & 0.001 \\
\hline
\end{tabular}


Table 5. Mann-Whitney U test

\begin{tabular}{|c|c|c|c|c|c|}
\hline & & \multirow{3}{*}{$\begin{array}{l}\text { Mann Whitney } \\
\text { U }\end{array}$} & \multirow{3}{*}{ Sig } & \multirow{2}{*}{\multicolumn{2}{|c|}{ MEAN RANK }} \\
\hline & & & & & \\
\hline & & & & $\begin{array}{l}\text { Public } \\
\text { Banks }\end{array}$ & $\begin{array}{l}\text { Private } \\
\text { Banks }\end{array}$ \\
\hline \multirow{4}{*}{ TANGIBLE } & Modern looking equipment & $3,353.500$ & 0.409 & 82.45 & 88.55 \\
\hline & $\begin{array}{l}\begin{array}{l}\text { Physical facilities } \\
\text { appealing }\end{array} \\
\text { visually }\end{array}$ & $2,713.500$ & 0.004 & 74.92 & 96.08 \\
\hline & Employees have neat appearance & $2,582.000$ & 0.001 & 73.38 & 97.62 \\
\hline & $\begin{array}{l}\text { Materials associated with service } \\
\text { visually appealing }\end{array}$ & $2,497.000$ & 0.000 & 73.38 & 83.38 \\
\hline \multirow{5}{*}{ RELIABILTY } & $\begin{array}{l}\text { Promises to do something by a } \\
\text { certain time fulfilled }\end{array}$ & $1,984.500$ & 0.000 & 66.35 & 104.65 \\
\hline & $\begin{array}{llll}\begin{array}{l}\text { Sincere interest in solving } \\
\text { customers' problems }\end{array} & \\
\end{array}$ & $1,707.500$ & 0.000 & 63.09 & 107.91 \\
\hline & $\begin{array}{l}\text { Perform the right service at the first } \\
\text { time }\end{array}$ & $1,920.000$ & 0.000 & 65.59 & 105.41 \\
\hline & $\begin{array}{l}\text { Provide the service at the time they } \\
\text { promise to do so }\end{array}$ & $2,454.000$ & 0.000 & 71.87 & 99.13 \\
\hline & Error free record & $2,319.500$ & 0.000 & 70.29 & 100.71 \\
\hline \multirow{4}{*}{$\begin{array}{l}\text { RESPONSIVENE } \\
\text { SS }\end{array}$} & $\begin{array}{l}\text { Banks tell customers exactly when } \\
\text { services will be performed }\end{array}$ & $3,410.500$ & 0.515 & 83.12 & 87.88 \\
\hline & Prompt service & $2,664.000$ & 0.002 & 74.34 & 96.66 \\
\hline & Willing to help customers & $3,355.000$ & 0.412 & 82.47 & 88.53 \\
\hline & $\begin{array}{l}\text { Never be too busy to respond to } \\
\text { customers' requests }\end{array}$ & $3,025.500$ & 0.061 & 78.59 & 92.41 \\
\hline \multirow{4}{*}{ ASSURANCE } & $\begin{array}{l}\text { Employee behaviour instil } \\
\text { confidence in customers }\end{array}$ & $2,816.500$ & 0.011 & 86.14 & 94.86 \\
\hline & Feel safe in transactions & $2,715.500$ & 0.004 & 96.05 & 74.95 \\
\hline & Employee courteous & $3,604.000$ & 0.978 & 85.40 & 85.60 \\
\hline & $\begin{array}{l}\text { Employees have knowledge to } \\
\text { answer customers' questions }\end{array}$ & $3,148.000$ & 0.132 & 80.04 & 90.96 \\
\hline \multirow{5}{*}{ EMPATHY } & Individual attention to customers & $3,570.000$ & 0.891 & 85.00 & 86.00 \\
\hline & Convenient operating hours & $3,468.500$ & 0.640 & 83.81 & 87.19 \\
\hline & Give customers personal service & $3,450.000$ & 0.603 & 83.59 & 87.41 \\
\hline & $\begin{array}{l}\text { The Bank has their customers' best } \\
\text { interest at heart. }\end{array}$ & $3,311.500$ & 0.327 & 89.04 & 81.96 \\
\hline & $\begin{array}{l}\text { Understand the specific needs of } \\
\text { their customers }\end{array}$ & $3,483.000$ & 0.678 & 83.98 & 87.02 \\
\hline
\end{tabular}

